Бондаренко Е.B.

\title{
ПРОБЛЕМЫ ПОЛИТИЧЕСКОГО ПРОЦЕССА В ЗАПАДНОЙ БЕЛОРУССИИ ПОСЛЕ РАЗГРОМА ГРОМАДЫ (1928 - 1939 гг.)
}

Аннотация: Рассматриваются основные тенденции политического процесса, воздействовавщие на него факторы и его трансформация в Западной Белоруссии после разгрома Белорусской крестьянско-рабочей Громады в условиях авторитаризачии политического режима во Второй Речи Посполитой в 1928 - 1939 г2. Анализируются основные субъекты политического процесса в рассматриваемом регионе и сочиальные аспекты их функиионирования, а также влияние на процесс политики польских властей в отнотении прожсивавшего в нем белорусского населения в контексте геополитического значения Западной Белоруссии ("северо-восточных кресов"). Исследование основано на междисииплинарном подходе, с использованием как общенаучных - анализа, синтеза, индукиии и дедукиии, так и специально-научных - системного, исторического методов. Научная новизна исследования заключается в том, что впервые в отечественной политической науке предпринята попытка рассмотрения политического процесса в Западной Белоруссии в условиях авторитаризации политического режсима во Второй Речи Посполитой.Основные выводы: в Западной Белоруссии после разгона Громады польскими властями, наблюдалась картина, свидетельствовавшая о снижении интенсивности и, вместе с тем, значительном разнообразии протекавшего здесь политического прочесса. Существенной его чертой была достаточно высокая роль относительно внутренних факторов развития прочесса внешнего его конструирования, возможного в результате относительно невысокого идейно-конфликтного потенциала украинского и белорусского обществ.

Review: The present research article is devoted to the main tendencies of political developments, factors influencing political developments and transformation of political developments in Western Belarus after the crushing defeat of the Belarusian Peasants' and Workers' Union 'Hramada' under the conditions of the authorization of the political regime in the Second Polish Republic since 1928 till 1939. The researcher analyzes the main actors of the political process in the region and social aspects of their functioning as well as the influence of the policy implemented by the Polish government regarding Belarusian population living in Poland. All these aspects are being viewed taking into account the important geopolitical role of Western Belarus (northeastern Kresy). The researcher bases his research on the interdisciplinary approach and uses both general scientific research methods such as analysis, synthesis, induction and deduction and particular scientific research methods such as the systems approach and historical analysis methods. The scientific novelty of the research is defined by the fact that this research is the first attempt made in Russian political science to describe political developments in Western Belarus under the conditions of the authorization of the political regime in the Second Polish Republic. The main conclusions made by the researcher are the following: Western Belarus after the crushing defeat of Hramada by the Polish government faced the decrease of intensity and at the same time quite a diversity of political developments. An important feature of the political developments in Western Belarus was a prevailing role of external factors compared to the internal factors triggering the development of the political process. That become possible as a result of a relatively low potential of ideological conflicts between Ukrainian and Belarusian societies.

Ключевые слова: политический прочесс, Западная Белоруссия, авторитаризаиия политического режима, Вторая Речь Посполитая, Громада, КПЗБ, Хадеция, Змаганне, Центросоюз, Белсанация.

Keywords: political developments, Western Belarus, authorization of the political regime, Commonwealth of Poland ('Second Polish Republic'), Hramada, Communist Party of Western Belarus, Chadecja, Zmahannie, Central Union, Belsanacja.

$\mathrm{A}$ ктуальность темы настоящей статьи обусловлена тем, что Западная Белоруссия представляла собой один из наиболее крупных регионов Второй Речи Посполитой, имевший, несмотря на преобладание непольского населения, значительное геополитическое значение для страны. Оно проявлялось, во-первых, в том, что её территория была кратчайшим «мостом» между Средней и Западной 
Европой и СССР. Во-вторых, регион представлял собой кратчайший путь для потенциальной экспансии «красного мира» на запад, в Среднюю и Юго-Восточную Европу, равно как и для вероятного вторжения с запада на восток: наиболее вероятное наступление противника на Советские Республики должно было произойти именно Западную Белоруссию.

Цель статьи - рассмотрение тенденций развития политического процесса в Западной Белоруссии после разгрома «Громады» в условиях нарастания авторитаристских тенденций во Второй Речи Посполитой.

Поднимаемая в настоящей статье тема изучена недостаточно. Тем не менее, отдельные проблемы, актуальные с точки зрения рассматриваемой в настоящей статье темы, имеют достаточно длительную историю изучения. В советских исследованиях послеоктябрьского периода истории Западной Украины и Западной Белоруссии, имевших место в период с конца 1940-х до второй половины 1980-х гг., доминировала такая черта, как комплексное рассмотрение вопросов их социально-экономической и политической истории, происходившее на основании архивных данных. Особое внимание обращалось на «революционную» борьбу трудящихся за воссоединение Западной Украины и Западной Белоруссии с УССР и БССР соответственно.

Вопросы, связпанные с политическим процессом, рассматривались в научных работах советского периода под углом анализа национального («колониального») гнета белорусов со стороны поляков, борьбы за национальное освобождение первых «под руководством» КПЗУ, борьбы за «интернациональную солидарность» рабочего движения и коммунистических партий Западной Белоруссии с советскими ВКП(б) и КП(б)Б. Преимущественное внимание исследователей обращалось к национальному и «революционному» движению - крестьянскому и рабочему - на порубежной территории довоенной Польши, направленное против польских «оккупантов», социальному положению разных категорий восточнославянского населения «северо-восточных кресов». Всё это рассматривалось в контексте влияния «Великого Октября» (С. Макарчук, П. Ольшанский, Н. Мезга, А. Ващенко, Э. Багинский, М. Лось, Ю. Гошко, И. Мараш, И. Заболотний, Р. Оксенюк, И. Зильберман, А. Мацко, М. Кравец, О. Швыдак, и др.). При этом акцент справедливо делался на тесной взаимосвязи национального и социального дви- жения белорусов, однако, не показана различная социальная база движущих сил этих двух направлений, а также собственно этнические процессы. Так, белорусы нередко вполне обоснованно отождествлялись с крестьянством, которое обладало очень развитым национальным самосознанием, - данная установка является уже спорной, собственно же коммунистическое движение было выразителем национально-освободительных устремлений (И. Полуян). Тематика этнополитического и этнокультурного развития изучалась сквозь призму деления его на «прогрессивное», так или иначе обращенное в сторону социалистического строя и Москвы (Минска) и «буржуазно-националистическое» - ориентировавшееся на собственные силы и возможности, а также на европейские страны.

Главным минусом данных работ, несмотря на привлечение в них обширного фактического и документального материал, во многом схраняющего свою актуальность и для современных исследований, являлось то, что методологическая база, в течение десятилетий оставалась слабой, будучи недостаточно развитой, односторонней и основанной на трудах классиков марксизма-ленинизма, идеологии КПСС и КПБ, всецело зависимой от политической конъюнктуры касательно белорусского вопроса и вызванной ею установок властей на определение этнической карты.

Внимание современных белорусских историков обращено преимущественно на политические и культурные элиты национального движения, этническое самосознание белорусской крестьянской массы остается недостаточно исследованным (С. Токть), равно как украинского крестьянства. Особенностью белорусской историографии можно считать локальность исследований (в рамках ряда сборников научных статей по белорусской истории в целом и её западных областей - в частности ${ }^{1}$ ), от-

\footnotetext{
1 Шестидесятилетие образования Гродненской области. Материалы Международной научной конференции 3-4 марта 2004 года. Гродно, 2004; Асоба у гісторыі: гераічнае і трагічнае. Матэрыялы Другой міжнароднай навукова-практычнай канферэнцыі студэнтау, аспірантау і маладых вучоных, прысвечанай памяці прафесара У. У. Мелішкевича. 12 - 13 литопада 2004 г. Брэст, 2006; Заходні рэгіён Беларусі. Вачыма гісторыкау і краязнауцау. Зборнік навуковых артикулау. Гродна, 2006; Этнасацыяльныя і культурныя працэсы у заходнім рэгіёне Беларусі: гісторыя і сучаснасць. Матэрыялы республіканскай навуковай канферэнцыі. 5 - 6 снежня 1997 года. Гродна, 1998.
} 


\section{Политика и общество 5 (113) • 2014}

сутствие тенденций к национализму (У. Ладысев, Э. Мазько, В. Черепица) и повышенное внимание к истории КПЗБ (В. Ласкович) как одного из ключевых западнобелорусских патриотических институтов в межвоенный период. Центрами изучения рассматриваемой в настоящей статье проблематики в современной Белоруссии являются Гродно и Брест, в Польше - Торунь и Белосток.

Западная Белоруссия, хотя и вошла в состав Второй Речи Посполитой по итогам Рижского мирного договора 18 марта 1921 г., не являлась регионом, где польское население преобладало. Согласно переписи 1931 г., белорусскую речь признали родной 903,6 тыс. православных жителей региона, а польский язык - 497,3 тыс. чел. [18, с. 81]. В общей сложности, население трех Западнобелорусских воеводств - Полесского, Новогрудского и Виленского, а также Гродненского и Волковысского поветов Белостокского воеводства, составляло в 1931 г. 3850 тыс. чел. [18, с. 17]. При этом, в городах процент белорусов распределялся, по данным переписей 1919 и 1921 гг., неравномерно. Если в Лиде и Браславе было соответственно 14\% и 15\% белорусского населения, то в Кобрине и Пинске $80,5 \%$ и $78 \%$.

Этническая картина Западной Белоруссии практически совпадала с социальной градацией «город-деревня»: если городское население региона состояло преимущественно из евреев, поляков и русских, а также немалого числа полонизированных белорусов, то белорусская интеллигенция и в целом белорусский народ как таковой были практически полностью представлены жителями деревни или выходцами из нее. Именно крестьянство составляло основную социальную базу белорусского национального движения в межвоенный период, в том числе, его политической составляющей. Следует отметить, что в межвоенный период белорусская интеллигенция как один из основных ресурсов национального развития и движущая сила политического процесса была настолько недостаточной по своей численности, что не могла пополняться в такой степени, которая требовалась для должного его обеспечения.

Можно выделить следующие факторы политического процесса в Западной Белоруссии в предвоенное десятилетие. Во-первых, его социокультурная база сформировалась в Российской империи. Во-вторых, необходимо признать наличие доста- точно слабой идеологической базы белорусского движения. В-третьих, белорусы, будучи третьим по численности народом в составе Второй Речи Посполитой, по сравнению с другими национальными меньшинствами, не представляли серьезной внутренней проблемы для польского правительства. Оно было готово до определенного времени мириться с их учреждениями и организациями, если они не выдвигали требования независимости и не были связаны с коммунистами. Однако, на местном уровне политика полонизации белорусского населения проводилась уже с начала 1920-х гг., будучи основана на ассимиляторской концепции польских национал-демократов. В первые годы после Майского переворота 1926 г. она заметно смягчилась, но к рубежу 1920-1930-х гг. произошло фактическое сворачивание всех «поблажек» в отношении белорусского большинства населения.

В значительной степени, в силу отмеченной слабости белорусской национальной интеллигенции, в течение межвоенного периода белорусы, в сравнении с рядом других национальных меньшинств, проживавших во Второй Речи Посполитой, создали значительно меньшее количество политических партий и организаций. Белорусское национальное общественно-политическое движение 1920-1930-х гг. группировалось вокруг трех основных лагерей: 1) пропольского, ориентированного на сотрудничество с властями, даже ценой отказа от требования независимости Белоруссии; 2) национально-демократического, охватывавшего организации, стоявшие на почве создания белорусской государственности; и 3 ) революционно-просоветсткого, представленного партиями, выступавшими за присоединение Западной Белоруссии к БССР и кардинальные социально-экономические преобразования. Социальной базой последнего был рабочий класс, беднейшее сельское население, городская беднота и часть интеллигенции, а также просто недовольные политикой правящих кругов Польши. Именно усилиями данного направления в Западной Белоруссии был создан фундамент для массового белорусского движения. Базой же демократического лагеря в целом были национальная польская, еврейская и немногочисленна белорусская буржуазия и интеллигенция, помещики и зажиточные слои крестьянства, средние городские слои. Что касается пропольских групп, то ни одной из них в течение межвоенного периода не уда- 
лось выйти на первый план в белорусской политической жизни в границах довоенной Польши. Их деятельность, как правило, поддерживалась польскими властями, и прекращение финансирования обычно приводило к концу их функционирования. Вместе с тем, в среде «полонофилов» наблюдались постоянные споры и конфликты.

В целом, вне зависимости от конкретной политической программы и социальной платформы, в довоенной Польше не было ни одной белорусской партии, которую устраивала бы ситуация, сложившаяся после подписания Рижского мирного договора. Каждая из них в своей программе на первом месте ставила объединение белорусских земель - за исключением КПЗБ или БКРГ. Для большинства белорусских политиков выбор ориентации на Польшу или БССР был в равной степени злом, не представлявшем каких-либо перспектив для Белоруссии.

На территории Западной Белоруссии в 1921 - 1939 гг. в общей сложности действовало около 40 политических партий разных направлений. При этом, главным центром белорусской общественнополитической жизни в течение 1921 - 1938 гг. является Белорусский Национальный Комитет (БНК), объединявший в разное время представителей от 19 до 40 белорусских партий и национальных общественных, культурных, образовательных и хозяйственных организаций и товариществ, включая Белорусскую Крестьянско-Рабочую Громаду, Товарищество Белорусской Школы и мн. др. Следует отметить устойчивую тенденцию, проявлявшуюся в том, что белорусские национальные политические партии демократического характера были немногочисленными и практически не влияли на массы.

В политическом процессе в Западной Белоруссии в контексте участия в нем белорусского населения в межвоенный пенриод можно выделить следующие этапы:

1) 1921 - 1925 гг.: период перманентного наступления со стороны польских властей на права белорусского населения, у которого имелась тенденция к возрастанию политической активности во главе с белорусской национальной интеллигенцией, сопровождавшаяся процессом активного партогенеза;

2) 1925 - 1928 гг.: период максимальной интенсивности политического процесса, наивысшего подъема политической активности белорусского населения вокруг, главным образом, БКРГ («Громады»);
3) 1928 - 1934 гг.: этап постепенной редукции политического процесса после разгрома польским властями «Громады» при неудачной попытке постановки его Варшавой под строгий контроль, что проявилось в планомерном сокращении таких показателей, как представительство белорусов в польском парламенте, география и объем вовлечения населения в активную политическую жизнь, нарастании среди него политической пассивности при развитии деятельности нелегального коммунистического движения;

4) 1935 - 1939 гг.: период институциональной деконструкции политического процесса белорусского населения в условиях перехода польских властей к осуществлению программы национальной ассимиляции последнего. В данной статье подробно рассматриваются последние два периода.

Важно отметить, что первая половина 1920-х гг. для Западной Белоруссии прошла в полувоенной обстановке - по причине активных действий белорусских «партизанских» отрядов и жесткой борьбы с ними польского правительства, а также угрозы разжигания польско-литовской войны. В 1923-1924 гг. на территории Западной Белоруссии действовало около 6 тыс. «партизан», объединенных в 4 штаба под общим руководством Главного Белорусского штаба, они осуществили около 300 боевых операций ${ }^{2}$. Группы партизан в количестве 50-150 человек неожиданно для властей совершали внезапные нападения на поселения или разные объекты. Неудивительно, что польская администрация Западной Белоруссии значительно резче, чем на территории этнографической Польши, реагировала на проявления национального движения ${ }^{3}$

В этих условиях уже в 1921 г. польские власти приступили к реализации «мирной полонизации» территории Западной Белоруссии. Более конкретно, полонизировать Западную Белоруссию предполагалось по трем основным направлениям. Во-первых, через создание массовых общественно-политических организаций, таких как «Союз поляков в восточных кресах». Во-вторых, как уже отмечалось, путем опоры на местное польское на-

\footnotetext{
2 Цярністы шлях уз'яднання. Круглы стол, прысвечаны 70-годдзю паходу Чырвонай арміі у Заходнюю Беларусь // Беларуская думка. 2009. № 9. С. 22.

3 Лучнін М. Заходняя Беларусь под панаваньем Польшчы. Менск, 1926. С. 49.
} 


\section{Политика и общество 5 (113) • 2014}

селение и полонофильские элементы среди иных национальностей, в частности, оказания поддержки белорусам в случаях, когда те, например, действовали против русских ${ }^{4}$. В-третьих, широко пропагандировались идеи польской державности и её исторических корней в регионе ${ }^{5}$.

Кромеэтого,польскиевластиустановилив 68белорусских городах систему местного самоуправления, во многом подобную той, которая имелась у городов Польского Королевства. И сами же поляки заполнили её структуры. Власти очень часто пользовались правом роспуска городских рад, а с 1926 г. и вовсе старались не допускать выборов в тех из них, где преимущество имела бы оппозиция т.к. после Майского переворота 1926 г. остро стоял вопрос заполнения вакантных мест в органах самоуправления приверженцами правительственного курса. В то же время, в конце 1930-х гг. рады избирались в основном по «компромиссным спискам» ${ }^{6}$.

Белорусская Крестьянско-Рабочая Громада была самой масштабной белорусской национальной организацией межвоенного периода, существовавшая с 30 июня 1925 г. по 30 марта 1927 г. Её предшественница - Белорусская Социалистическая Громада, первая белорусская национальная политическая партия, была основана еще в 1902 г. и просуществовала до лета 1918 г. Сама же БКРГ оформилась в июне 1925 г., когда группа левых депутатов Белорусского посольского клуба во главе с Б. Тарашкевичем вышла из него и создала собственный Посольский клуб белорусской крестьянско-рабочей громады (БКРГ). Они составили ЦК Громады в следующем составе: Б. Тарашкевич (председатель), С. Рак-Михайловский (заместитель председателя), П. Метла (казначей), П. Волошин и М. Бурсевич. Остальные члены БПК во главе с Ф. Яремичем

\footnotetext{
${ }^{4}$ Любимов Л. Д. На рубеже новой Европы. Очерки современной Польши. Париж, 1930. С. 76.

${ }^{5}$ Нечухрын А. М., Васюк Г. У., Ганчароу М. М., Карау Д. У., Коукель I. І., Кручкоускі Т. Т., Фёдарау Е. А. Этнасацыяльная і палітычныя прцэсы $\check{y}$ заходнем рэгіёне Беларусі $\check{y}$ 1921 - 1939 гг. // Этнасацыяльныя і культурныя працэсы у заходнім рэгіёне Беларусі: гісторыя і сучаснасць. Матэрыялы республіканскай навуковай канферэнцыі. 5 - 6 снежня 1997 года. Гродна, 1998. С. 81.

${ }^{6}$ Борка А. I. Дзейснасць градскіх радау ў Заходняй Беларусі у 20 - 30-е гг. XX ст. // Заходні рэгіён Беларусі. Вачыма гісторыкау і краязнауцау. Зборнік навуковых артикулау. Гродна, 2006. С. 157, 159.
}

сформировали другую партию - Белорусский Крестьянский Союз (БКС).

В национальном вопросе руководители Громады ставили ряд требований к польским властям: полной автономии Белорусской Национальной Рады, равноправия нацменьшинств, населяющих Белоруссию, при этом отстаивали принцип полного самоопределения народов, а также широкого развития белорусской культуры и национализацию школ. Однако свою популярность в среде белорусов Громада получила в значительной степени благодаря радикализму социальных требований программы. Но они были целиком популистскими, а большинство идей БКРГ - абсолютно нереальными для выполнения в условиях польского владычества. Уже в течение 1926 г. партия увеличила численность своих рядов до 90 тыс. чел. ${ }^{7}[4$, с. 71], причем особенно стремительный рост рядов Громады наблюдался после Майского переворота: в течение июня - сентября 1926 г. количество её членов возросло с 950 до 45 тыс. чел. ${ }^{8}$

Для подавляющего большинства белорусских крестьян Громада была надеждой на изменения, силой, которая напомнила об их человеческих и гражданских правах, партией, которая громко говорила о польской кресовой власти то, что о ней думало большинство белорусов. Она была организованной формой протеста против унизительной действительности. Тактика же лидеров интересовала немногих. В итоге, к моменту своего закрытия 21 марта 1927 г., партия насчитывала около полутора сотен членов 9 . В некоторых деревнях в Громаду вступало все взрослое мужское население, однако, за массовостью скрывалась внутренняя слабость организации. Одним из признаков этого можно рассматривать то обстоятельство, что закрытие БКРГ не вызвало массовых акций протеста в Западной Белоруссии.

Успех «Громады» диктовал правительству Польской Республики необходимость предприни-

\footnotetext{
${ }^{7}$ Вонсовский Б., Рудомина Г. Куда Пилсудский ведет Польшу? М., 1927. С. 71.

${ }^{8}$ Токть С. М. Динамика этнического самосознания крестьянского населения Западной Белоруссии в 1920-1930-х годах // Белоруссия и Украина: История и культура: Ежегодник/ Кол.авт. Институт славяноведения РАН. М., 2004. С. 293.

9 Ласкович В. П., Ласкович В. В. Подвиг Коммунистической партии Западной Белоруссии (КПЗБ). 1919 - 1939. Исторический очерк. Брест, 2002. С. 131.
} 


\section{Политические режимы и политические процессы}

мать срочные действия в целях удержания белорусов в покорности польскому руководству. Осенью 1926 г. Л. Василевский представил проект под названием «О вопросе белорусской политики польского правительства в данный момент». В нем содержался призыв к немедленному изменению курса в отношении белорусского образования. Вскоре сотрудникам польской администрации было указано на желательность знания белорусского языка. В 1928 г. от белорусских земель в сейм и Сенат было избрано, соответственно, 10 послов и 2 сенатора-белоруса, причем, 26\% проголосовавших отдали свои голоса КПЗБ ${ }^{10}$. А на муниципальных выборах белорусы получили 20\% мест в городских и гминных радах, правда, многие из них являлись представителями проправительственных партий. Они провели 6 - 7 ноября в Вильно Съезд белорусских радных, в котором приняли участие около 80 делегатов из гминных рад Виленского, Новогрудского и Белостокского воеводств. На нем был поднят и обсужден широкий круг вопросов - репрессии против белорусского образования, чрезмерно высокие налоги, негативное отношение властей первой инстанции к белорусам ${ }^{11}$. К 1929 г. подобные послабления были свернуты. В последующие годы национальную политику на подведомственных территориях определяли местные власти.

После ликвидации БКРГ 21 марта 1927 г., западнобелорусское политическое движение не смогло уже достичь такого размаха, но, при этом, значение КПЗБ в политическом процессе и жизни рассматриваемого региона в целом не уменьшалось. При этом, середина 20-х - начало 30-х гг. характеризовались стремлением к сочетанию легальных и революционных форм борьбы. Основной организацией, ориентированной на белорусское национальное развитие, после 1927 г., можно считать Товарищество Белорусской Школы (ТБШ).

Фактическим антиподом и, в глазах Варшавы, противовесом КПЗБ была Белорусская Христианская демократия («Хадеция»; БХД), оформившаяся как движение в 1926 г. и представлявшая идеоло-

\footnotetext{
${ }^{10}$ Токть С. М. Динамика этнического самосознания... // Белоруссия и Украина: История и культура: Ежегодник. С. 295.

${ }^{11}$ Gomolka K. Ruch białoruski w przededniu II wojny światowej // Беларускі Гістарычны Зборнік / Bialoruskie Zeszyty Historyczne. 2000. Nr. 13. // URL: http://kamunikat.fontel.net/ www/czasopisy/bzh/13/13kom_gomolka.htm
}

гию клерикального национализма. Она представляла ряд общественно-политических организаций: Белорусский Крестьянский Союз, Белорусский Православный Союз, Виленский Белорусский Народный Комитет, БХД называла себя «надклассовой» и «надполитической» партией, не принимала идеи ассимиляции национальных меньшинств, антисемитизма, консерватизма в земельном вопросе, резко критиковала капитализм. Ее идеология базировалась на тезисе о христианской сущности и будущем белорусского народа, живущего в независимой демократической республике, демократичность которой вытекала из самой сущности, духа христианства. Руководство движения взяло на себя миссию «будителей» национальных начал белорусов, последовательно высказывалось за создание белорусского национального государства и всестороннее развитие белорусского народа.

К парламентским выборам, состоявшимся в марте 1928 г., белорусское национальное общественно-политическое движение представляло собой четыре отдельных лагеря: БХД, КПЗБ и «Змаганне», ядро будущей «Белорусской санации», а также пропольские силы. На этих выборах КПЗБ набрала 328,8 тыс. голосов - 26\% всех голосовавших в Западной Белоруссии ${ }^{12}$.

После выборов 1928 г., наиболее успешных для белорусов Польской Республики за весь межвоенный период, в польском Сейме были созданы два белорусских посольских клуба - во главе с Ф. Яремичем и Я. Гавриликом. Последний с мая 1929 г. именовался «Белорусский крестьянско-рабочий посольский клуб» (БКРПК). Первый же декларировал в качестве главной цели своей деятельности борьбу за национальную независимость, второй противодействие «эксплуатации капиталистов и помещиков без различия национальностей» ${ }^{13}$, а его парламентская тактика находилась под руководством КПЗБ. Представители БПК в 1928 г. предприняли попытку создания Украинско-белорусского сеймового клуба (УБСК), с тем, чтобы он

\footnotetext{
${ }^{12}$ Мацкко A. Н. Деятельность компартии Польши и компартии Западной Белоруссии по организации трудящихся масс на борьбу против гнета буржуазии и помещиков (1918 1938 гг.): автореф. дисс. ... Д-ра ист. наук. Мн., 1968. С. 36.

13 Пашкевіч А. В. Парламенцкія формы змагання за нацыянальныя і сацыяльныя правы беларускага народа ў міжваеннай Польшчы (1921 - 1930). Мн., 2006. С. 80.
} 


\section{Политика и общество 5 (113) • 2014}

объединил различные белорусские политические силы, составлявшие бы, при этом, его автономные части. Объединение с украинцами дало возможность белорусским послам войти в состав некоторых, впрочем, второстепенных по значимости, сеймовых комиссий. В ноябре 1928 г. белорусские послы заявили о выходе из УБСК. Также следует указать на упомянутую выше попытку создания украинско-белорусского политического конгресса в 1929 г., оказавшуюся неуспешной.

В период между парламентскими выборами 1928 и 1930 гг. политический режим Второй Речи Посполитой претерпел заметную эволюцию в сторону авторитаризации. Основу правительства составила так называемая «группа поклонников», включавшая лиц из окружения Ю. Пилсудского. На этом фоне сложилась следующая политическая конфигурация белорусского политического движения, на основе которой мог выстраиваться политический процесс в рассматриваемом регионе: левый БКРПК, БХД и солидаризировавшиеся с ней в Общебелорусский избирательный комитет и, наконец, «Центросоюз». Характерно, что руководство Общебелорусского избирательного комитета заключило с украинскими политическими кругами соглашение, согласно которому, а также исходя из своих реальных возможностей, ограничило свою деятельность территорией Новогрудчины, Лидчины, Виленщины и Свенцицщины ${ }^{14}$. Таким образом, к началу 1930-х гг. ареал деятельности активного белорусского общественно-политического движения сократился до размеров Виленского и Новогрудского воеводств, тогда как Полесское фактически оказалось под украинским влиянием, Гродненское же - преимущественно под промосковским коммунистическим. Парламентские выборы 1930 г. и подготовка к ним проводились уже в условиях экономического кризиса, что серьезно ограничивало возможности белорусских организаций. Они стали последними в довоенной Польше, в которых принимали участие белорусские партии, завершив собой институционализированный этап белорусского национального политического процесса.

Ключевой организацией правоцентристского направления в предвоенное десятилетие можно назвать так называемую «Белорусскую санацию», или «реабилитацию» (1928 - 1934 гг.; другое название

${ }^{14}$ Там же. С. 93.
- «Белорусское возрождение»), представлявшую собой умеренное крыло белорусского национального движения, развившее активную деятельность в 1920-е гг. Его лидерами являлись депутаты Сейма Б. Тарашкевич, С. Островский, А. Луцкевич, В. Богданович и др. В своем органе «Наперад» («Вперед») группа подчеркивала, что «не будет служить ни Москве, ни Варшаве». Главной своей задачей «Белсанация» видела создание альтернативного БНК национального центра, проведение работы на культурном поприще, в области национального возрождения. Ее ключевой организацией являлся так называемый «Центросоюз», или Центральный союз культурных и общественных организаций, созданный в августе 1930 г. после роспуска Сейма и назначения новых парламентских выборов.

Его руководители считали единственно возможным путем культурно-национального развития белорусского народа поиск компромиссов с правительством Ю. Пилсудского (о расширении его политических прав речь уже не шла), что в условиях авторитаризации политического режима представляло собой совершенно необходимое условие для любой общественной деятельности. В качестве первого практического шага вносилось предложение выделить три северо-восточных воеводства (Виленское, Новогрудское, Полесское) в отдельную административную единицу. Под организационным влиянием Центросоюза находились Товарищество белорусской школы, Белорусское научное общество в Вильнюсе, Белорусское благотворительное общество, Белорусский студенческий союз, Белорусский женский союз, родительские комитеты белорусских гимназий и другие культурно-просветительные общества и общины, имевшие потенциал для влияния, пусть и косвенного, на белорусский национальный политический процесс.

Однако, выборы в польский сейм в ноябре 1930 г. закончились провалом «Центросоюза»: он не получил ни одного мандата и затем, с 1932 г., когда Педагогический совет белорусской гимназии в Новогрудке решил из него выйти, влияние этой организации постепенно сокращалось.

В то же время, представители КПЗБ, также как и КПЗУ, по итогам выборов 1930 г. в Сейм не прошли, при этом экономический кризис вызвал значительный рост числа членов КПЗБ, активным деятелем которой в эти годы стал Б. Тарашкевич. Таким образом, на рубеже 1920 - 1930-х гг. бе- 
лорусское национальное политическое движение претерпело заметные изменения. Во-первых, произошла вынужденная маргинализация левых сил; во-вторых, центристским и пропольским силам, несмотря на все старания польских властей, не удалось получить сколько-нибудь значительного успеха у белорусского населения; в-третьих, общая политическая активность белорусского населения к началу 1930-х гг. резко упала, чему способствовала политика польского руководства, направленная на всяческое ослабление любых неугодных правительству общественно-политических сил и движений и препятствовавшая формированию «изнутри» белорусского национального сегмента в политическом процессе Второй Речи Посполитой, заполняя его искусственно сознаваемыми правоцентристскими организациями типа «Белсанации» и «Центросоюза». На характере участия населения именно в левых политических движениях сказывалась и нерешенность множества социальных проблем белорусов.

Если по заметно сфальсифицированным итогам выборов в польский парламент 1930 г. прошли всего три депутата-белоруса, из них двое - по списку ББСП, то в 1935 и 1938 гг. - ни одного. Выборы в Сейм 1935 г., состоявшиеся после принятия новой Конституции польской Республики и смерти Ю. Пилсудского, в Западной Белоруссии также проводились с внушительной фальсификацией, как и на «восточных кресах» в целом. Зачастую в отдельных населенных пунктах, особенно удаленных от городов, число пришедших на избирательные участки было мизерным. Так, во многих деревнях в голосовании принимали участие не более $5 \%$ населения ${ }^{15}$. В отдельных же избирательных округах число «проголосовавших» и вовсе значительно превышало число реально проживавшего в них населения ${ }^{16}$.

Дальнейшему развитию «Центросоюза» воспрепятствовал конфликт, возникший в 1933 г. между его руководителями, в частности, Островским и А. Луцкевичем. Первый, в итоге, выдвинул план «гармоничного сосуществования» белорусов и поляков, чем фактически положил конец

\footnotetext{
${ }^{15}$ Мигун Д. 17 сентября в истории страны. К вопросу о воссоединении Западной Белоруссии и БССР в 1939 г. // Беларуская думка. 2009. № 9. С. 30.
}

${ }^{16}$ Любимов Л. Д. Указ. соч. С. 58 - 59. своему авторитету в белорусской среде. В течение его существования Центросоюз критиковали хадеки, коммунисты и прочие белорусские группы - за то, что им представлялось угожденчеством и излишнюю, на их взгляд, лояльность при осуществлении контактов с польскими правящими кругами. Наконец, он не имел серьезной общественной поддержки. Последние структуры «Центросоюза» распались к началу 1937 г.

Серьезный удар по развитию белорусского национального движения был нанесен в 1933 г., когда большинство руководителей БКРГ, КПЗБ и клуба «Змаганне» оказались в СССР в результате обмена заключенными между двумя странами и в 1937 1938 гг. стали жертвами сталинских репрессий. Роспуск же КПЗБ, состоявшийся 15 августа 1938 г. ${ }^{17}$ Еще 2 января 1937 г. Сталин высказался за роспуск КПЗБ. При этом, принятие Постановления ИККИ о роспуске КПП и её двух «дочерних» партий было нарушением устава Интернационала: его руководство не имело права распускать партию, тем более ту, которая участвовала в создании Коминтерна.

Репрессии против руководства западно-белорусского национального движения привели к окончательной ликвидации остававшихся к этому времени немногочисленных организованных структур белорусского движения на «кресах». Польская дефензива проводила аресты белорусских деятелей даже в августе 1939 г., за несколько дней до нападения нацистской Германии ${ }^{18}$.

Особая ситуация складывалась на крайнем западе ареала проживания белорусского населения. Район Белостокского повета относился к территориям с преимущественно польским культурным влиянием, что заметно давало о себе знать. В 1933 - 1934 гг. на Белосточчине действовало белорусское кооперативно-издательско-просветительское общество «Сяуба». Но оно не сумело развить серьезного национального движения в этой области. Белорусский деятель Станислав Гринкевич так характеризовал настроения в крестьянстве на Белосточчине в 30-е гг.: «Массового белорусского движения нет. <..> Нет... и политического сознания... До настоящего времени на-

\footnotetext{
${ }^{17}$ Мацко А. Н. Борьба трудящихся Польши и Западной Белоруссии против фашизма (1933 - 1939 гг.). Мн., 1963. С. 165.

${ }_{18}$ Шыбека 3. Нарыс гісторыі Беларусі (1795 - 2002). Мн., 2003. C. 275.
} 


\section{Политика и общество 5 (113) • 2014}

род живет только сегодняшним днем... не выходя за границы своей деревни или прихода. Народ не верит в свои силы, с недоверием смотрит на все окружающее...» ${ }^{19}$. Похожая ситуация с середины 1930-х гг. наблюдалась практически во всех воеводствах Западной Белоруссии.

Следует отметить, что, несмотря на наступление польских властей на белорусское политическое движение на ребеже 1920-1930-х гг., экономический кризис 1929 - 1933 гг. вынудил польские власти заниматься иными проблемами, нежели ассимиляция белорусов. Затем происходит реактивация данного направления. В ноябре 1933 г. Новогрудский воевода С. Свидерский представил свои предложения по решению белорусской проблемы. Его план предусматривал постепенное сокращение числа существующих белорусских культурных, образовательных, экономических и политических учреждений и недопущение появления новых. И он был утвержден министром внутренних дел Ф. Славой-Складковским, а затем, реализован, главным образом в области образования.

В 1935 г. по инициативе Ф. Акинчица, еще в феврале 1931 г. исклюенного из «Центросоюза», была предпринята попытка создания Белорусской национально-социалистической партии, ориентированной на нацистскую идеологию, которая была запрещена последовательно всеми западнобелорусскими воеводами в 1937 г.

Ввиду роста реального влияния КПЗБ на белорусское население в предвоенное пятилетие остановимся на её функционировании как решающей политической силы нелегального политического субпроцесса более подробно. Принятие в 1935 г. новой конституции Польской Республики, которая законодательно ограничивала демократические права и свободы граждан, сближение с гитлеровской Германией (в 1934 г. был заключен германо-польский пакт о ненападении) свидетельствовали об усилении политической реакции в стране. В этих условиях руководство КПЗБ стало отходить от прежних сектантских позиций. Решающий поворот был сделан на II съезде КПЗБ (8-18 мая 1935 г.). ЦК КПЗБ определил задачу создания широкого демократического, антифашистского народного фронта путем вовлечения в него организаций социал-демократи-

${ }^{19}$ См. Грынкевич С. «3 родное Сакольшчыны». Цит. по Токть С. М. Динамика... - С. 297. ческих партий, БХД на основе общей борьбы за демократические свободы, насущные социально-экономические требования населения.

В августе-сентябре 1935 г. состоялись три официальные встречи представителей ЦК КПЗБ и ЦК БХД. Была достигнута договоренность по совместному сбору деклараций за открытие белорусских школ, издание белорусской грамматики. Создан Центральный школьный секретариат, который распространил в деревне свыше 127 тыс. деклараций, 1259 заявлений и 1205 инструкций на открытие государственных начальных белорусских школ.

КПЗБ делала шаги по установлению единства действий с организациями ППС, Бунда и «Стронництва людове» Вильнюса, Белостока, Гродно, Барановичей, Лиды, Сувалок и Волклвыска. В основу были положены основные демократические и социально-экономические требования. В течение конца 1935 - начала 1936 г. общие комитеты и комиссии были созданы на некоторых предприятиях Белостока, Вильно, Гродно, Баранович, Волковыска. В 1936 г. состоялись 184 инспирированные КПЗБ забастовки, в которых участвовало около 40 тыс. рабочих. Политические выступления рабочих, митинги и демонстрации, как правило, координировались «единофронтовыми» комитетами. Усиливалась борьба крестьян, направленная на отсрочку налогов, против комасации и окончательной ликвидации сервитутов и так далее. Широкий резонанс получила забастовка нарочанских крестьян-рыбаков, которая началась весной 1935 г. В ней участвовало около 5 тыс. крестьян из более 40 окрестных деревень ${ }^{20}$.

После этих событий белорусский вопрос приобрел значительно большую значимость и постепенно выходил на широкую политическую арену, стал предметом дискуссий и в Сейме.

Значимой тенденцией политического процесса можно считать то, что происходила радикализация интеллигенции и студенческой молодежи. В 1935 - 1936 гг. в Вильно действовала легальная антифашистская организация - Союз студенческой левицы «Фронт», который объединял студентов и представителей виленской интеллигенции разных национальностей. Организация выступала за осуществление демократических и социальных преобразований, поддерживала право на самоо-

\footnotetext{
${ }^{20}$ Гісторыя Беларусі ХІХ - XX ст. Мн., 2001. С. 356.
} 
пределение Западной Белоруссии. Возглавляли организацию представители польской прогрессивной интеллигенции Г. Дэмбинский и С. Ендрыховски. Она издавала газету «Просто».

В августе 1937 г. началась Общепольская забастовка крестьян, охватившая около 1 млн. человек. Ее поддержали крестьяне Бельского, Гродненского и Слонимского уездов. В то же время проводилась акция в защиту С. Притыцкого, который, выполняя приговор КПЗБ, стрелял в провокатора, агента дефензивы Стральчука в зале Вильнюсского окружного суда. Волна протеста против смертного приговора, которая проводилась и в БССР, и значительная социальная нестабильность в крестьяской среде вынудила польские власти заменить смертную казнь пожизненным заключением.

С 1936 г. «Хадеция» официально называлась «Белорусское народное объединение», от которого отделился «Белорусский Народный Фронт» во главе с В. Годлевским. В его программе по-прежнему отстаивался принцип независимости Беларуси, говорилось о борьбе против «диктатуры капитализма, фашизма и коммунизма». Программа ориентировала населения на «третий путь» развития общества через организацию кооперативов, просветительско-хозяйственных кружков, библиотекчитален и др. Представители данной партии также выступали с протестом против преследований и издевательств над деятелями культуры и науки в БССР, которые обвинялись в национал-демократизме и контрреволюционной деятельности. В 1937 г. удар был нанесен и по этому направлению белорусского движения: деятельность БИХиК поставлено польскими властями под запрет, а вместе с ней и печатный орган белорусского католического движения «Беларуская Крыница» и, кроме того, ТБШ, закрытое 23 марта. Последние легальные организации, имевшие хотя бы косвенное влияние на белорусский национальный политический процесс в составе Второй Речи Посполитой, прекратили свое существование.

В 1938 г., после ликвидации КПЗУ, всех белорусских учебных заведений и практически всех имевшихся на тот момент культурно-образовательных и просветительских учреждений, БИХиК, ТБШ и БНК и аннулирования представительства белорусов в польском парламенте, польские власти официально признали белорусскую проблему решенной. Однако даже после умиротворения белорусского движения представители администрации и полицейские относились к местному населению, как к побежденному противнику.

На фоне такого хода событий Белорусское Народное Объединение (БНО) в 1937 - 1939 гг. выдвинуло лозунг «культурного сожительства». Он предусматривал солидарность и сотрудничество разных слоев общества в деле развития национальной и общечеловеческой культуры как основу демократического строя. Чем они выше, тем цивилизованнее нация. Соответственно, представители преобразованной «Хадеции» выступали против идеологии диктатуры любого класса и социальной группы. Практической реализации демократизма в стране, согласно идеологам хадеков, поспособствовало бы установление системы гминного, поветового и воеводского самоуправления. В его компетенцию должны были входить административные, экономические, образовательные, земельные и социальные вопросы. Для успешного решения этих дел органы самоуправления должны иметь свой бюджет. Утверждалось, что «каждое государство, которое угрожает существованию этнических различий своих национальных меньшинств и, вместо создания условий для естественного развития, уничтожает и преследует их - поступает аморально» ${ }^{21}$.

Опираясь на приведенные принципы, в конце 1938 г. руководство БНО начало поиск союзников среди других национальных меньшинств, главным образом, литовцев и украинцев. Однако отношения с последними охладились в результате спора о северной границе ареала их проживания.

Исходя из обозначенных выше установок, в феврале 1939 года БНО требовало от всех своих сторонников и членов принять участие в местных выборах: «Белорусы! В отсутствие белорусских экономических и культурных организаций мы должны все наше внимание и энергию сосредоточить на территориальном самоуправлении - громадском и гминном, и поветовых радах. Местное самоуправление в Республике является ведущей организацией местного населения. Нынешнее самоуправление - крестьянско-социальные и гминное, а также поветовые рады с точки зрения управления расположены в од-

\footnotetext{
${ }^{21}$ Мазько Э. Хрысьціянска-дэмакратычная канцэпцыя беларускай дзяржаўнасьці (у кантэксьце дзейнасьці заходнебеларускіх партый 20-30-х гг. XX ст.) // Беларускі Гістарычны Зборнік/Bialoruskie Zeszyty Historyczne. 2001. Nr. 16.
} 


\section{Политика и общество 5 (113) • 2014}

ном повете и, поэтому, не охватывают весь спектр потребностей целого ряда местностей Республики. Такое самоуправление является первичным публично-правовым институтом защиты интересов местного населения, выразителем его настроений, а также большой школой социально-экономического развития и побудителем широкого внешкольного образования» ${ }^{22}$.

После того, как избирательная кампания не принесла белорусским избирателям успеха, в июне 1939 г. руководство БНО обратилось к Виленскому воеводе с просьбой возобновить поставленные вне закона белорусские организации и восстановить белорусское начальное и среднее образование, но и здесь не добились результата.

После ликвидации КПЗБ активную деятельность развила БНСП, созданная в 1935 г. Ф. Акинчицем по образцу гитлеровских организаций и занимавшаяся прокладыванием пути к национально-политическому и социально-экономическому освобождению белорусского народа. Этот путь предполагал борьбу как с «польско-католическим», так и с «православно-марксистским» духовенством. Руководство Национал-социалистической партии рассчитывало на поддержку молодежи, разочарованной в существующей действительности. Но оно рассматривалось польскими властями в качестве гитлеровских агентов, и они чинили всевозможные препятствия для деятельности БНСП. Впрочем, в 1939 г. и в её среде, и у «хадеков» появлялось все больше надежд на могучего западного соседа Польши.

30 июня 1939 г. Белостокский воевода Осташевский послал в Министерство внутренних дел новую программу под названием «Проблема укрепления польского элемента в Белостокском воеводстве». Документ, насчитывающий более 160 страниц машинописи, содержал анализ экономической, социальной и политической ситуации в регионе, а также предложения для дальнейших действий властей и соображения насчет решения национальных проблем. Непольское население, отмечалось, составляло в воеводстве более 33 процентов всех жителей. Воевода предлагал, прежде всего, повысить уровень жизни поляков, создать условия для ми-

\footnotetext{
${ }^{22}$ Gomolka K. Ruch białoruski w przededniu II wojny światowej // Беларускі Гістарычны Зборнік / Bialoruskie Zeszyty Historyczne. 2000. Nr. 13. // URL: http://kamunikat.fontel.net/ www/czasopisy/bzh/13/13kom_gomolka.htm
}

грации белорусского сельского населения в города, где существовала естественная среда для ускорения их полонизации. Осташевский отмечал, что «препятствием для расширения польской культуры является значительная плотность белорусского населения, которое встречается с польским населением, стоящим еще ниже культурно». Повышение материального и культурного уровня поляков сделало бы их естественными пропагандистами польской культуры в белорусской деревне. Роль правительства в процессе ассимиляции Осташевский рассматривал в первую очередь во влиянии на восточнославянское население посредством школы, разветвленной сети библиотек с польской литературой, при одновременном устранении влияния белорусской. В Белостокском воеводстве в 1939 г. существовала уже только одна белорусская организация - бакалейный кооператив, и 56 польских с числом членов более 180 тыс. чел. Проблема заключалась лишь в невысоком уровне их влияния на белорусскую среду, которая, как из-за недостаточно открытого отношения поляков, так и своего собственного недоверия к ним, оставалась вне досягаемости их воздействия. Существующие же в белорусской среде пророссийские симпатии будил православный клир и коммунистическая пропаганда ${ }^{23}$. Против господства первого было заострено движение православных поляков, что же касается коммунистов, то они ко времени составления программы находились полностью на нелегальном положении и были своими же единомышленниками из СССР лишены собственной организации годом раньше.

23 июля 1939 г., фактически, уже итоги полонизаторской политики в Западной Белоруссии оценил тот же белостокский воевода Осташевский: «Процесс ассимиляции, о котором могла быть речь, когда говорили об укреплении польского господствующего положения на этом участке, со времени возрождения Речи Посполитой не достиг значительных результатов. Белорусский элемент сознательно содействовал движению прорусской ориентации. В первом ряду стояли здесь довоенные русские симпатии» ${ }^{24}$.

\footnotetext{
${ }^{23}$ Mironowicz E. Białorusini, komunizm i władze sanacyjne w latach 1937-1939. // Беларускі Гістарычны Зборнік / Bialoruskie Zeszyty Historyczne. 2006. Nr. 25. S. 113.

${ }^{24}$ Молочко Н. П. О прожитом и пережитом. Минск, 1989. C. 14 .
} 
Таким образом, в Западной Белоруссии после разгона Громады польскими властями, наблюдалась картина, свидетельствовавшая о снижении интенсивности и, вместе с тем, значительном разнообразии протекавшего здесь политического процесса. Существенной его чертой была достаточно высокая роль относительно внутренних факторов развития процесса внешнего его конструирования, возможного в результате относительно невысокого идейно-конфликтного потенциала украинского и белорусского обществ. Также отметим, что политический процесс, казалось бы, взятый к середине 1930-х гг. польскими властями под полный контроль, находил свое развитие в нелегальной обстановке, привлекая значительную часть политически активного населения и набирая интенсивность в зависимости от численности последнего в том или ином воеводстве, или даже повете.

После ликвидации БКРГ 21 марта 1927 г., белорусское национальное политическое движение в данном регионе не смогло уже достичь такого размаха. При этом, середина 20-х - начало 30-х гг. характеризовались стремлением к сочетанию легальных и революционных форм борьбы. Основной организацией, ориентированной на белорусское национальное развитие, после 1927 г., можно считать Товарищество Белорусской Школы (ТБШ).

В 1930-е гг. в политическом процессе западнобелорусского региона все большую роль начали играть белорусские национально-демократические партии и их координирующий орган - Белорусский национальный комитет. Вместе с тем, в предвоенное десятилетие возникают некоторые движения правого политического спектра и значительные усилия предпринимают представители КПЗБ.

В середине 1930-х гг. в западнобелорусском национальном общественно-политическом движении усилились дезориентация и идейно-политическая конфронтация. Лишь под влиянием решений VII Конгресса Коминтерна, с осени 1935 по осень 1936 г., наблюдались попытки налаживания сотрудничества между коммунистами, с одной стороны, и христианскими демократами и БИХиКом с другой, на предмет политического сотрудничества (создание антифашистского на- родного фронта) и совместной акции в поддержку белорусских школ, но были пресечены польской полицией и не сопровождались поддержкой Москвы.

Наиболее тяжелым за весь межвоенный период временем для белорусского населения Второй Речи Посполитой можно считать 1937 - 1939 гг., когда польские власти окончательно перешли к политике, направленной на полную национальную ассимиляцию первого, что предполагало фактически ликвидацию белорусского политического движения. Воссоединение Западной Белоруссии с ей восточной, советской частью, имело своим последствием для политического процесса его жесткую деформацию, произошедшую вследствие интеграции рассматриваемого региона в тоталитарное политическое пространство СССР.

\section{Библиография:}

1. Шестидесятилетие образования Гродненской области. Материалы Международной научной конференции 3-4 марта 2004 года. Гродно, 2004.

2. Айчынная і сусветная гісторыя: сучасныя погляды I метады даследаванняу. Зборнік навуковых прац у дзвюх частках. Частка 1. Актуальныя пытанні гісторыі Беларусі. Мн., 2000.

3. Асоба у гісторыі: гераічнае і трагічнае. Матэрыялы Другой міжнароднай навукова-практычнай канферэнцыі студэнтау, аспірантау і маладых вучоных, прысвечанай памяці прафесара У. У. Мелішкевича. 12 - 13 литопада 2004 г. Брэст, 2006.

4. Вонсовский Б., Рудомина Г. Куда Пилсудский ведет Польшу? М., 1927.

5. Гісторыя Беларусі XIX-XX ст. Мн., 2001.

6. Егоров Г. Западная Белоруссия. М., 1939.

7. Заходні рэгіён Беларусі. Вачыма гісторыкау i краязнауцау. Зборнік навуковых артикулау. Гродна, 2006

8. Ласкович В. П., Ласкович В. В. Подвиг Коммунистической партии Западной Белоруссии (КПЗБ). 1919 - 1939. Исторический очерк. Брест, 2002. . 


\section{Политика и общество 5 (113) • 2014}

9. Лучнін М. Заходняя Беларусь под панаваньем Польшчы. Менск, 1926.

10. Любимов Л. Д. На рубеже новой Европы. Очерки современной Польши. Париж, 1930.

11. Мазько Э. Хрысьціянска-дэмакратычная канцэпцыя беларускай дзяржаўнасьці (у кантэксьце дзейнасьці заходнебеларускіх партый 20-30-х гг. XX ст.) // Беларускі Гістарычны Зборнік/Bialoruskie Zeszyty Historyczne. 2001. Nr. 16.

12. Мацко А. Н. Борьба трудящихся Польши и Западной Белоруссии против фашизма (1933 - 1939 гг.). Мн., 1963.

13. Мацко А. Н. Деятельность компартии Польши и компартии Западной Белоруссии по организации трудящихся масс на борьбу против гнета буржуазии и помещиков (1918 - 1938 гг.): автореф. дисс. ... д-ра ист. наук. Мн., 1968.

14. Молочко Н. П. О прожитом и пережитом. Мн., 1989.

15. Пашкевіч А. В. Парламенцкія формы змагання за нацыянальныя і сацыяльныя правы беларускага народа ў міжваеннай Польшчы (1921 - 1930). Мн., 2006.

16. Токть С. М. Динамика этнического самосознания крестьянского населения Западной Белоруссии в 1920-1930-х годах // Белоруссия и

17. Украина: История и культура: Ежегодник/ Кол.авт. Институт славяноведения РАН. М., 2004. С. $286-304$.

18. Цярністы шлях уз'яднання. Круглы стол, прысвечаны 70-годдзю паходу Чырвонай арміi у Заходнюю Беларусь // Беларуская думка. 2009. № 9. С. 18-27.

19. Шыбека 3. Нарыс гісторыі Беларусі (1795 2002). Мн., 2003.

20. Этнасацыяльныя i культурныя працэсы у заходнім рэгіёне Беларусі: гісторыя і сучаснасць. Матэрыялы республіканскай навуковай канферэнцыі. 5 - 6 снежня 1997 года. Гродна, 1998.

21. Gomolka K. Białoruskie partie i organizacje prorządowe w II Rzeczypospolitej // Беларускі Гістарычны Зборнік/Bialoruskie Zeszyty Historyczne. 1997. Nr. 7. // URL: http://kamunikat.fontel.net/www/czasopisy/bzh/07/07art_ gomolka.htm
22. Gomolka K. Ruch białoruski w przededniu II wojny światowej // Беларускі Гістарычны Зборнік / Bialoruskie Zeszyty Historyczne. 2000. Nr. 13. // URL: http://kamunikat.fontel.net/www/czasopisy/bzh/13/13kom_gomolka.htm

23. Mironowicz E. Białorusini, komunizm i władze sanacyjne w latach 1937-1939. // Беларускі Гістарычны Зборнік / Bialoruskie Zeszyty Historyczne. 2006. Nr. 25. S. $102-115$

\section{References (transliteration):}

1. Vonsovskii B., Rudomina G. Kuda Pilsudskii vedet Pol'shu? M., 1927.

2. Gistoryya Belarusi XIX-XX st. Mn., 2001.

3. Egorov G. Zapadnaya Belorussiya. M., 1939.

4. Laskovich V. P., Laskovich V. V. Podvig Kommunisticheskoi partii Zapadnoi Belorussii (KPZB). 1919 - 1939. Istoricheskii ocherk. Brest, 2002. .

5. Luchnin M. Zakhodnyaya Belarus' pod panavan'em Pol'shchy. Mensk, 1926.

6. Lyubimov L. D. Na rubezhe novoi Evropy. Ocherki sovremennoi Pol'shi. Parizh, 1930.

7. Maz'ko E. Khrys'tsiyanska-demakratychnaya kantseptsyya belaruskai dzyarzhay̆nas'tsi (u kanteks'tse dzeinas'tsi zakhodnebelaruskikh partyi 20-30-kh gg. KhKh st.) // Belaruski Gictarychny Zbornik/Bialoruskie Zeszyty Historyczne. 2001. Nr. 16.

8. Matsko A. N. Bor'ba trudyashchikhsya Pol'shi i Zapadnoi Belorussii protiv fashizma (1933 1939 gg.). Mn., 1963.

9. Matsko A. N. Deyatel'nost' kompartii Pol'shi i kompartii Zapadnoi Belorussii po organizatsii trudyashchikhsya mass na bor'bu protiv gneta burzhuazii i pomeshchikov (1918 - 1938 gg.): avtoref. diss. ... d-ra ist. nauk. Mn., 1968.

10. Molochko N. P. O prozhitom i perezhitom. Mn., 1989.

11. Pashkevich A. V. Parlamentskiya formy zmagannya za natsyyanal'nyya i satsyyal'nyya pravy belaruskaga naroda y̆ mizhvaennai Pol'shchy (1921 - 1930). Mn., 2006.

12. Tokt' S. M. Dinamika etnicheskogo samosoznaniya krest'yanskogo naseleniya Zapadnoi Belorussii v 1920-1930-kh godakh // Belorussiya i 
Политические режимы и политические процессы

13. Shybeka Z. Narys gistoryi Belarusi (1795 2002). Mn., 2003.

14. Gomolka K. Białoruskie partie i organizacje prorządowe w II Rzeczypospolitej // Belaruski Gictarychny Zbornik/Bialoruskie Zeszyty Historyczne. 1997. Nr. 7. // URL: http://kamunikat.fontel.net/www/czasopisy/bzh/07/07art_gomolka.htm

15. Gomolka K. Ruch białoruski w przededniu II wojny światowej // Belaruski Gictarychny
Zbornik / Bialoruskie Zeszyty Historyczne. 2000. Nr. 13. // URL: http://kamunikat.fontel.net/www/czasopisy/bzh/13/13kom_gomolka.htm

16. Mironowicz E. Białorusini, komunizm i władze sanacyjne w latach 1937-1939. // Belaruski Gictarychny Zbornik / Bialoruskie Zeszyty Historyczne. 2006. Nr. 25. S. 102 $-115$ 